\title{
Indicaciones para presentación de artículos para la revista Perspectiva Geográfica
}

\section{Formato de presentación}

- Word

- Papel blanco bond, tamaño carta

- Márgenes: Izquierda, superior y derecha: $3 \mathrm{~cm}$. Inferior: $2 \mathrm{~cm}$.

\section{Texto}

- Digite el texto a espacio sencillo, utilice Times New Roman, tamaño 12.

- Título del trabajo: centrado, negrilla, mayúsculas.

- A doble espacio: nombre del autor en minúsculas, negrilla con asterisco como llamado para anotar: profesión, títulos e institución donde trabaja.

- Resumen: escriba la síntesis del trabajo en no más de 100 palabras.

- Palabras clave: identifique las palabras principales del trabajo.

- El resumen y las palabras clave, deben venir en español, inglés y francés.

- Títulos del trabajo, numeración arábiga centrados, mayúsculas fijas.

- Subtítulos: izquierdo, negrilla y minúsculas.

- Siguientes subtítulos: izquierdo, minúsculas para los siguientes aportes utilice literales.

- La extensión no debe ser mayor a 20 páginas.

\section{Tablas y figuras}

- Enviarlas en archivos separados especificando el Software, en tamaño carta con las márgenes ya mencionadas.

- Las tablas y figuras deben ser enumeradas correlativamente.

- Las figuras (gráficos, mapas, etc.) deben ser presentados en original, tamaño carta.

\section{Referencias bibliográficas}

- Citas textuales cortas incluidas en el texto principal van entre comillas, con su respectiva referencia (apellidos del autor, año de publicación y página exacta de donde se extrajo la cita).

- Transcriba las citas textuales demasiado largas con indentación izquierda a renglón sencillo, sin comillas y con referencia bibliográfica exacta.

- Las referencias generales a una fuente, identificarlas con el apellido del autor y el año de publicación.

- La lista de referencias bibliográficas deben aparecer alfabéticamente, utilice normas ICONTEC para su presentación. 
Perspectiva Geográfica Núm. 11,2005 333 